\title{
Nursing students' sense perception of communication in psychiatric hospital
}

\author{
Sensopercepção de graduandos de enfermagem na aprendizagem da comunicação em hospital psiquiátrico \\ Sensopercepción de graduandos de enfermería en el aprendizaje de la comunicación en un hospital psiquiátrico
}

\section{Albert Lengruber de Azevedo', Sílvia Teresa Carvalho de Araújo', Paulo Sergio da Silva", Rosane Mara Pontes de Oliveira', Virginia Faria Damasio Dutra'}

\author{
' Universidade Federal do Rio de Janeiro, Anna Nery Nursing School. Rio de Janeiro, Brasil. \\ "Universidade do Estado do Rio de Janeiro, Nursing School. Rio de Janeiro, Brasil.
}

\begin{abstract}
How to cite this article:
Azevedo AL, Araújo STC, Silva PS, Oliveira RMP, Dutra VFD. Nursing students' sense perception of communication in psychiatric hospital. Rev Bras Enferm [Internet]. 2018;71(Suppl 5):2280-6.
\end{abstract}

[Thematic Issue: Mental health] DOI: http://dx.doi.org/10.1590/0034-7167-2017-0957

Submission: 01-30-2018 Approval: 05-19-2018

\begin{abstract}
Objective: to analyze the sense perception of nursing students in the learning of communication in a psychiatric hospital. Method: qualitative, exploratory and descriptive, from representative drawings of the communication perceived by the body senses of 23 nursing students, and recorded enunciation of the remarkable experiences after the end of the practical activities. The data were analyzed according to thematic content. Results: the heart captures perceptions, favoring interpersonal relationships; smelling shows care lacking in hospitalization; vision monopolizes the impressions of reality, making the movements static; hearing is exercised in the amplitude to listen; touching demarcates limitations of contact and interaction; and tasting, as social sense, seeks to overcome the obstacles to take care. Conclusion: the learning of communication was significant, making the psychiatric hospital a space to listen to what is inside, to find in the emotions and rationalities the sensations that can be inside and outside the tension nodes that interfere in the perceptions.
\end{abstract}

Descriptors: Communication; Mental Health; Students, Nursing; Education, Nursing; Sensation.

\section{RESUMO}

Objetivo: analisar a sensopercepção de graduandos de enfermagem na aprendizagem da comunicação em hospital psiquiátrico. Método: qualitativo, exploratório e descritivo, a partir de desenhos representativos da comunicação percebida pelos sentidos corporais de 23 graduandos, e enunciação gravada das experiências marcantes após o término das atividades práticas. Os dados foram analisados segundo conteúdo temático. Resultados: o coração capta percepções, favorecendo as relações interpessoais; o olfato revela cuidados que faltam na hospitalização; a visão monopoliza as impressões da realidade, tornando estático os movimentos; a audição se exercita na amplitude para escutar; o tato demarca limitações de contato e interação; e o paladar, como sentido social, busca vencer os obstáculos para cuidar. Conclusão: a aprendizagem da comunicação foi significativa, tornando o hospital psiquiátrico, um espaço para escutar o que está no interior, para encontrar nas emoções e racionalidades as sensações, que podem estar dentro e fora, os nós tensionais que interferem nas percepções.

Descritores: Comunicação; Saúde Mental; Estudantes de Enfermagem; Educação em Enfermagem; Sensação.

\section{RESUMEN}

Objetivo: analizar la sensopercepción de graduandos de enfermería en el aprendizaje de la comunicación en un hospital psiquiátrico. Método: estudio cualitativo, exploratorio y descriptivo, a partir de dibujos representativos de la comunicación percibida por los sentidos corporales de 23 graduandos, y enunciación grabada de las experiencias notables después del término de las actividades prácticas. Los datos fueron analizados según el contenido temático. Resultados: el corazón capta percepciones, favoreciendo las relaciones interpersonales; el olfato revela cuidados que faltan en la hospitalización; la visión monopoliza las impresiones de la realidad, haciendo estático los movimientos; la audición se ejercita en la amplitud para escuchar; el tacto demarca limitaciones de contacto e interacción; y el paladar, como sentido social, busca vencer los obstáculos para cuidar. Conclusión: el aprendizaje de la comunicación fue significativo, haciendo del hospital psiquiátrico un espacio para 
escuchar lo que está en el interior, para encontrar en las emociones y racionalidades las sensaciones, que pueden estar dentro y fuera, los nudos tensionales que interfieren en las percepciones.

Descriptores: Comunicación; Salud Mental; Estudiante de Enfermería; Educación en Enfermería; Sensación.

\section{INTRODUCTION}

Awakening reflections during the training of nurses on the sense of communication in an area of health knowledge that puts affections, body and mind in the center of attention, requires of those who teach and learn this craft, a dip in different theories of mastery of nursing ${ }^{(1-3)}$. This knowledge, based on subjective assessments and clinical conditions, demands a content approach, from previous experiences, to be meaningful and easy to learn ${ }^{(3)}$.

Communicating is one of the competencies of the Lei de Diretrizes e Bases da Educação Nacional (Law on Guidelines and Bases of National Education), which has been developed during the training of health professionals, because it is a transversal element to care. In areas such as mental and psychiatric health, this learning is built on interaction, and it is hoped that those involved will be able, on principle, to establish therapeutic relationships with one another.

Depression, anxiety, bipolarity and schizophrenia are clinical conditions that may hinder interaction in the social environment, requiring therapeutic interventions guided by the interpersonal relationship. In a way, other clinical conditions can alter communication between people, affect their emotions and cognitions, with significant impairment in their skills, social development, beliefs and management of self-care and other diseases ${ }^{(3)}$.

To situate the nursing student in this context, to understand the constant valorization of the technologies in it, the inputs, the biological parameters and the prognostic descriptors of normality, is very important ${ }^{(1)}$. Because, in this way, he will learn not to exclude the various forms of sickness, suffering, pleasure, pain, fear, and yearnings, all generated in this model ${ }^{(1-2)}$. The challenge includes transposing the barriers where learning takes place, the use of cognitive or behavioral techniques, and the interpretation of facts and overcoming obstacles that generate communication noises ${ }^{(2)}$.

During professional training, in the daily encounters between nursing students and teachers, it is increasingly necessary to provoke a different know-how in these protagonists, since, for the one who conducts the whole process, the best way to encourage it is to involve it, to break with models still operative to teach, characterized by the unidirectional transmission of information that considers the office of care as receptacles of knowledge ${ }^{(3)}$.

In the process of teaching and caring in the health area, the object of intervention is unique and sensitive, which speaks, hears, looks, and desires, that is, man in its fullness. The agent who cares for and teaches this office lends its vital energy to the activity it develops, makes its creative and propositional capacity rich, assuming the position of driver, which creates, inspires and motivates. Exercising this plurality with the nursing student is permeated by the perceptions, desires and desires during the training, requiring, in the set of the rationality of nursing care required, the effectiveness of teaching methodologies that privilege the use and recognition of expressions and emotions.

These transformations, not so recent in the area of health in general, in mental and psychiatric health, carry daily challenges that fall on individuals, families, health professionals, health services, patients and also universities. This space should be rich in experience, unique for the exchange of new experiences, so that part of a list of attributions can actually contribute to the training of professionals, future care providers and, more specifically, the care of people in situations of psychosocial care ${ }^{(4)}$.

Actions, such as the creation of new spaces for dialogue and reach, not only about who the people need to learn, but also how to perform or receive nursing care during training are fundamental, for the intentionality of improving communication skills and avoiding breaking of personal barriers, possible to be mediated during the pedagogical process ${ }^{(3)}$.

\section{OBJECTIVE}

To analyze the sense perception of nursing students in the learning of communication in a psychiatric hospital.

\section{METHOD}

\section{Ethical aspects}

In this study, the authors were concerned with compliance with the national and international precepts of Ethics in Research involving Human Beings, being approved by the Brazil platform. All nursing students were guaranteed anonymity, coding their names in the alphanumeric sequence (E1, E2, E3, ... E23), according to the order of participation. Those who chose to participate in the proposed moments were guaranteed the right to leave, if they wished, without implying any future risks for their training. Fortunately, there was no refusal.

\section{Theoretical and methodological framework}

The knowledge produced is anchored in the six steps of the research group, the Sociopoetics method, which allows to explore the cognitive potential of sensations, emotions, gestures, imagination, intuition and reason, promoting creativity in learning, knowing, not researching and caring for human beings $\mathrm{s}^{(5)}$.

\section{Type of study}

This is a qualitative, exploratory and descriptive study, from representative drawings of the communication perceived by the body senses and the recorded enunciation of the remarkable experiences after practical activity in psychiatric hospital. 23 male and female students of both sexes, regularly enrolled in the seventh period of the course, participated verbally expressing their desire to participate in the study. Those who experienced previous situations 
of care for patients suffering from psychological distress, such as nursing technicians and nursing assistants, were not part of the study.

\section{Methodological procedures}

Initially, a schedule of meetings with the teaching coordinator was made, obeying the scheduled dates in the pedagogical activities schedule. From this, two meetings were made exclusively for the production of research data. It was established that the first meeting would take place before the commencement of practical activities in the psychiatric hospital, and that the second meeting would be at the end of the practical field activities, that is, after forty-five days. Both meetings were preceded by the realization of a breakfast, called "Affective Coffee", whose purpose is the affiliation of the researcher, designated as facilitating element, next to the researched group. These proposed activities happened respectively in April and May, 2013. It should be emphasized that access to nursing students occurred only after contact with the teachers responsible for teaching content Mental Health Nursing.

\section{Study setting}

It was a classroom, a public institution of higher education, in the city of Rio de Janeiro - RJ, southeast region of Brazil. This room was chosen because it is located within a complementary health unit at the University. Its operation takes place in full time, preserving the teaching-learning of hospitalization, and favoring the knowledge of other therapeutic modalities for the care of the person in psychological distress.

\section{Collection and data Organization}

The activity began with the performance of a relaxation to the sound of instrumental music, followed by the reading and signing of the Informed Consent Term and the activity for individual data production. Initially, an A4 sheet was distributed, dotted on it in the form of a planned cube, for free construction of drawings, a play technique titled "Game of Chance". The nursing students were guided on this activity from the following guiding question: What is the meaning of communication for you in the psychiatric hospital? Each drawing was accompanied by a phrase or word that represented it. This meeting lasted about thirty minutes.

Subsequently, in the enunciation phase, which lasted for forty minutes, each student shared the meaning of his design, thus enabling a collective discussion about the different personal and academic conceptions and histories about the care given to the client in the hospitalization.

In the lockdown phase of the researcher, which happened after the collective validation of the drawings produced by the nursing students, the transcriptions of the recorded testimonies, the floating reading, the exhaustive re-reading and the triangulation of the data were carried out, by the convergence of significance of the records. The synthesis of the results came from the grouping of the drawings that resembled in each of the six faces of a great cube. It was emphasized that there was no pretension to analyze the drawings, and that they were the driving force behind the sharing of each nursing student about the meaning of communication in the psychiatric hospital.

In the second meeting, an individual tool, called "Experience of the Socio-communication Senses of the Body", printed on A4 sheet, composed of six questions about perception through each sense of the body (eye, nose, mouth, hands, ear and heart), was delivered to nursing students for completion and subsequent sharing. This meeting lasted approximately forty minutes.

Subsequent to this step, the exhaustive reading and analysis of the results of both tools were carried out to identify the units of meaning in them, which dealt with the sense perception of nursing students in the learning of communication in a psychiatric hospital.

\section{Data analysis}

The data obtained in the two meetings were triangulated, following the same criteria, and analyzed according to the thematic content of Bardin ${ }^{(6)}$. A great category has been identified that it calls itself - communication perceived by the bodily senses.

\section{RESULTS}

This study counted on the participation of nursing students, mostly in the age group between 20 and 24 years (21) and 25 to 27 years (2), with predominance of females (19) and single women (23), which significantly may reflect the availability of time and dedication to professional training. And as a way of fostering understanding about the relationships that people establish with one another, four (n: 4) nursing students shared that the heart sense is responsible for capturing perceptions and sensations in care.

When the therapeutic relationship is established, the theoretical knowledge walks with the heart. And through sensitivity I was able to identify this [...] I saw areas that needed more attention. (E.2)

During care my heart records the affection and bond that these users had during the internship, and how I modified my behavior, interest, communication, bonding with them. (E.8)

Mercy and compassion. There is a mixture of fear of being in a situation of that, or seeing a relative of yours go through that [...] the will is to help, to be useful. (E.13)

The restlessness, the anxieties [...] the way they approach their life stories [...] is that kind of communication that my heart records during the care. (E.14)

The perception captured and translated by the bodily senses of five (n: 5) nursing students showed that smelling reveals missing and necessary care during hospitalization. Smelling characterizes the environment and people, reflecting the long hospitalization.

Lack of hygiene care. (E.1)

With smelling, we have identified whether patients need guidance on hygiene. And from this, if the problem is social or health. (E.2)

The smell represents a lot of the personality of the person. [...] when we choose a perfume ihere is a lot of our identity. (E.9)

Hygiene can be assessed through smelling, contributing to record the needs of care to the bearer of psychological distress. (E.10)

The smell of the food served in the institution reminds me of the anxiety experienced by the users during the care due to the short time that they are prepared for the meals. (E.15) 
By touching, communication is described by six (n: 6) nursing students as the one that demarcates contact limitations in interaction and care.

Touching was a cautious approach, as patients may abuse it a bit. At most, handshakes. (E.2)

After a more positive interaction with the users, they changed the way they greeted me [...] they hugged me or changed their handshake. (E.15)

The needing [...] of the hug [...] I often felt hugged by the patients. [...] The need of touch, of contact, makes them more needy. (E.21)

In touch, there is a detachment that needs to be maintained due to the libido of the patients. (E.5)

I believe that there is a careful touching [...] not only to not be confused as exaggeration of approach and a bit of fear for hygiene. (E.13)

In relation to the touch [...] when the patient wishes to establish a more intense contact with the professional they shake hands, approach, embrace. This kind of communication that my touch records. (E.14)

In vision, communication is described by five (n: 5) nursing students as responsible for monopolizing the impressions of reality and for paralyzing movements, keeping the bodies static.

From vision, we have the first impression of the patient, and from then on we can identify some demands of care. (E.2)

I could see through the observation that the attitude and dressing said a lot about the state of the user [...] demonstrates a form of communication. (E.7)

Their expressions, articulations and behaviors [...]. Visual perception contributes to the assessment of mood, behavior, etc. This assessment helps to conduct and establish the necessary care. (E.10)

My vision records time passing by [...] as a setting of a drama film [...] I see the patient as a character who suffers not only with his disorder, but with bad spiritual energies coming from the environment in who is stuck. (E.16)

It records the general aspect of [the patient], such as his clothing, hygiene, and what he may be representing to him, for example: the patient is vain [...], but there is a day when he is careless [...] this may seem like he's not well, he's in crisis. (E.23)

Communication by hearing is described by six (n: 6) nursing students as one who exercises in the range of listening to the patient, standing by and not holding him/her.

With the psychiatric patient this was the most used sense [...] and that I was able to enhance. [...] This patient shows a great need to be heard. And listening needs to be active [...], he needs to realize that what he says is important. (E.2)

[...] Listening to the problems, the joys [...] with this I evolved as a professional. (E.9)
Hearing provides understanding the problem and feelings of the patient [...]vision together with hearing is the perfect combination for the care. (E.11)

My hearing records someone who suffers and cries for help, who needs to be heard and understood. (E.16)

A great lack of the patient in wanting to be heard, in wanting to speak what feels [...] to want attention. (E.19)

The need for help [...] there is an individual locked inside each patient; I hear fantastic life-experience reports that have been interrupted by pathology. (E.21)

Tasting is symbolized by three ( $\mathrm{n}: 3)$ nursing students by the mouth, pointed to as social sense, which seeks to overcome obstacles to interaction.

Sometimes I feel a lot of nausea because of that unpleasant smell. [...] it's unpleasant. (E.1)

My taste records a bitter taste of solitude and suffering contained. (E.16)

I lack the taste [...]. In fact, there is concern with tasting, with what the patient feels. (E.18)

The artistic production carried out in the two meetings with the nursing students considered the units of signification present in the structures of thought on verbalized and non-verbalized communication, characterizing the need for attention to the care that is lacking and necessary in hospitalization.

\section{DISCUSSION}

In this experience, the communication skills acquired by nursing students were numerous and, if they were not shared as if they were seized, they could place the person in a psychiatric hospital at a different level of the person, in a psychiatric hospital, in another plan of teaching, learning and $\operatorname{care}^{(7)}$.

The value and experience of researching from the bodily senses to (re) signify communication in nursing care in this context was fundamental, due to the possibility of perceiving and improving the interactions with the person in psychological distress.

Communication from the heart sense was pointed out as showing at every moment the feelings and sensibilities of others, favoring perceptions, attention, affection, gratitude, constant desire to want to help, empathy, fear, and the provision of a care of hygiene and comfort ${ }^{(8)}$.

In speaking of the heart sense, nursing students state that they need to be more available, to perform a more humanized care and as close as possible to the patient, seeking to help them achieve their socialization. Emphasis on communication in this context was relevant, as it allowed the nursing student to think, with greater depth of meanings, in their own meanings, actions and possibilities. Life and communication go together, form a binomial, do not separate, for where life ends, it automatically puts an end to every possibility of communicating.

In this experiment, the heart sense revealed the influence of affection on the interaction of the nursing student with the 
patient, increasing his interest in reaching care. Through affection, there was the recognition that caring at the psychiatric hospital requires the investment of technologies such as: fostering, bonding and co-responsibility. It then came to mean: extending the person's condition of life, which is a social being, to help him meet his basic demands, health and also citizenship ${ }^{(9)}$.

The smelling was pointed out by the nursing student as meaning nothing silent/noisy, for being the most direct of the senses of the body, whose sensory effects are immediate. And although the perfume is a revealing of care, and the bad odors that generate repulsion, both can alter the interaction between people, increase detachment and direct physical contact, significantly interfering with the patient's daily personal hygiene ${ }^{(3,8)}$.

Bad odors may indicate that something is wrong with the person, either due to lack of hygiene or significant physical alterations of a disease, thus requiring intervention ${ }^{(3,8)}$. Here, the bad odors were attributed by nursing students to the demands of hygiene care, and reported to self-care, self-esteem, self-concept, hopelessness, human dignity, and body and self-care.

The great challenge that requires the rupture of administrative obstacles of the psychiatric hospital is to encourage the nursing student to think that the construction of an established planning can and should consider fixed and non-fixed schedules to meet, in a singular way, the demands inherent in the person, mainly related to meal times and hygiene care, which need and must always be compatible with the desires and behavioral responses of each person.

The vision was described by nursing students as the matrix that attributes special meaning to the content of the perception of immediate communication, which generates behaviors capable of altering interaction and care $^{(8)}$. Touching through the gaze is a form of communication to the lack and limitation, through spontaneity, expressiveness and affectivity ${ }^{(3)}$. And in the interaction with the patient, the touch can be expressive-instrumental, when combined with the technical and expressive abilities.

Through the vision, the nursing students have been able to perceive the power that the eyes have over the perceptions, which, when sharpened, can favor the look on the practice of the psychiatric hospital, seeing it in a much more open, holistic and not only symbolic way ${ }^{(10)}$. Perceiving in the clinical assessment elements that go beyond the said, the realized, is possible by the vision, which functions as stereoscopic binoculars, great monopolizers of the senses, since $70 \%$ of the sensory receptors are located in the vision. It is for this reason, perhaps, that abstract thinking wages a constant struggle between judgment and understanding of what the eyes actually see.

In touching communication, nursing students were able to recognize that touching is based on procedural memory, that is, on doing, demonstrating with accuracy of $70 \%$ the female $e^{(3,7)}$. And, by different sensory stimuli during childhood, adolescence and adulthood, different emotions may be between men and women; and depending on what one wishes to express, its location can also be differentiated, as well as its effects and the singular description between the one who touches and is touched ${ }^{(11-12)}$.

In this teaching-learning opportunity, touching revealed, in depth, the acquisition of communication skills acquired by nursing students, the awareness of the importance of the interpersonal relationship of safety to efficiency, and of care, being clear the sensitivity maintained to perceive and help the patient, and the strategies proposed to meet the demands of care ${ }^{(13-14)}$. The possibility of touching each other and letting oneself be touched can mean, in a way, a way of being in the world ${ }^{(15)}$.

By touching, it was evident the need for physical caution on the part of the nursing students during the interaction with patients, a necessary distance, and that can be translated as a request for help, a way to think, to reflect, to plan interventions, and to take care of before even to perform any task at the psychiatric hospital.

After this experience, nursing students recognized that the touch is found throughout the body, both internally and externally to the skin. It was part of your reality and in some particular circumstances. Touching with their eyes, full-bodied and also on the inside, required them to learn from their emotions before they even reached each other, interacting and caring.

Behavioral responses related to sexuality are patterns of difficult control on the part of patients suffering from psychological distress. To encourage the nursing student's understanding of the clinic, marked by suffering and madness, uncensored, favors reflection on the increase of libido, abuses, exaggeration of movements and emotions, which require all the time and at all times care and care, common in proxemics, characterized by the position of the bodies in the interaction ${ }^{(3,8)}$.

And, to understand how to act, and how nursing students feel and approach patients in psychological distress, the rational brain analyzes the facts and interprets external events, while the emotional brain assesses the internal states, both essential, for do not disregard the very biochemistry that signals the emotions.

In communication from the hearing, the nursing students described the importance of affective and effective listening. They consider that they have heard reflectively in the communicational and interactional scope, and that they have experienced support as a therapeutic measure in understanding themselves and the other, with involvement and participation in listening $^{(15)}$. Listening with the senses is pointed out as a strategy to become active in action, to improve listening, interaction and care $^{(8)}$. When the prejudice about madness is overcome, there is more ability for interaction, care and learning on both sides.

The act of listening inwardly, of revisiting oneself before hearing the other, should be understood as a learning opportunity. In the psychiatric hospital, the willingness to listen is fundamental, first because it helps in the recognition of who he is, for later understanding about the disease and the clinical symptoms that may arise from it; and second, to find answers to actions, reactions and approximations consenting or not, and can interfere directly in the interaction with the patient ${ }^{(8)}$.

In this experience, listening was shared as a potent therapeutic resource, contributing to humanization and improving interpersonal relationships ${ }^{(8)}$. Attitudes such as being available to listen, allowed the nursing student to access the subjective human field, meaning: problem solving, availability, understanding, trust, respect. When listening is effective, it improves the patient's condition and expression; when it is deficient, hinders such expressions, corroborating with the worsening mental state and the maintenance of life ${ }^{(16)}$.

To listen, in situations of crisis, or even in those where patients present behavioral changes, such as, for example, in catatonia, where bodies become paralyzing and static for listening, contact, 
interaction and movements, it becomes a challenge, especially when what is sought is to sensitize him to daily hygiene and feeding.

Communication from the tasting allowed nursing students to reflect on their own perceptions and behaviors, identifying their strengths and weaknesses ${ }^{(2)}$. The ability of therapeutic communication, while increasing the confidence of the nursing student, decreased the level of their anxiety, positively influencing the affectionate attitude toward the care environment ${ }^{(17-19)}$.

By tasting, nursing students were recognized for their own attractiveness and/or repulsion behavior, both because of fear and difficulty in getting involved with patients, and because they wanted to correct the body's lack of hygiene care. The initiative to go as far as one felt safe depended on how each one sees the nuances and the nuances of the senses, texture to look at and see the situations that are established, which are often different and different along the way of practice, and difficult to break.

And to repair situations of difficulty of interaction, it is important to remember the importance of other conceptual displacements: to accept tasting as a way of communicating in the world, and also to accept it as social sense; to assume that it is a territory of the senses, sensations and emotions, sociocommunicantes, that communicates through colors, odors, aromas, flavors and emotions generated in the care environment.

In this exercise that marked the learning of communication in the psychiatric hospital, care was seen as a main actor, because, without him, knowledge would be doomed to the end, and there were no conditions for the driving force of knowledge to penetrate new spaces and public spaces. And it is this world dimension that the student must give to knowledge, to make it infinite and unfinished, difference in people's lives ${ }^{(20)}$.

Nursing education should be directed, therefore, to health care, to improve interpersonal relationship, social inclusion, psychosocial rehabilitation, and interprofessional care. When associated to integration, nursing care may favor nursing students in their training and also in their future performance, considering all the collective and social context, based on a new model of care that is rehabilitating, comprehensive and humanizing ${ }^{(17-20)}$.

The dialogical space constructed in the discipline allowed the development of a sensitive listening through the senses, functioning as a field of knowledge about illness, a device of self-awareness, self-knowledge, and the scientific knowledge of the profession ${ }^{(3,19,21)}$. This was a playful and light space to share things that are often heavy because of the complexity of relationships and subjectivities.

\section{Study limitations}

The reduced number of participants, when compared to the general enrollment in the course and in the curricular program of nursing, in the area of mental and psychiatric health, and in the fact that this academic experience has 90 hours of practical classes, which can be considered as little time to modify anxieties and prejudices as, for example, justify fear of touch by sexuality and odor.

\section{Contributions to the Nursing}

The research method considered pioneer ludic activities through the senses of the body to deal with the complexity involved in the perception of self and the other; aspects of intersubjectivity present in the context of mental health; the opportunity to reflect on the intervening factors, and on the positive pedagogical strategies to teach and learn the unique care during the training of nurses.

\section{FINAL CONSIDERATIONS}

The knowledge produced in this study allowed the understanding that nursing teaching about communication in the psychiatric hospital should be linked to the valorization of the relationship with the other, being at the center of the approach to the person, to promote self-knowledge and to achieve success in learning of care. The body speaks, and in order to encourage the nursing student to interpret it naturally, it was necessary to slowly redo the flow between looking, seeing, feeling, thinking and reacting, for the senses are intimately connected to these perceptions, to the sensible ones. To train the perception is to think in the sensations, is to accept that the care and the approximation can make it easier.

Significant learning about communication has made the psychiatric hospital a space to listen to what is inside, to find in emotions and rationalities the sensations that can be inside and outside, the tensioning nodes that interfere with perceptions, and the truth that dwells and time delay.

This was the soft and creative way to teach and learn care, and it enriched the exchange of knowledge, practices, experiences and facts between nursing students and teacher, reflective encouragement, individual and group polyphony, formulation of criticism, liberation of creativity, autonomy, solidarity, awareness, and exercise of commitment in the process of thinking about life and care in the area of mental and psychiatric health.

Teaching-learning strategies, assisted by the sociocommunication senses of the body, functioned as a powerful tool in the production of self-knowledge of the nursing student, a source of learning and intellectual, psycho-affective, interactive and emotional capacities. know-how that impacts on the interaction, and the care provided by the nursing student.

\section{REFERENCES}

1. Dib EP, Abraão JLF. Uma experiência terapêutica pré-cirúrgica: o uso do desenho como mediador lúdico. Bol Psicol[Internet]. 2013[cited 2017 Nov 02];63(139):159-74. Available from: http://pepsic.bvsalud.org/pdf/bolpsi/v63n139/v63n139a05.pdf

2. Rosenberg S, Gallo-Silver L. Therapeutic communication skills and student nurses in the clinical setting. Teaching and Learning in Nursing[Internet]. 2011[cited 2017 Nov 26];6(1):2-8. Available from: http://www.jtln.org/article/S1557-3087(10)00041-7/pdf

3. Azevedo AL, Figueiredo NMA, Silva PS, Cardoso MMVN, Porto IS, Araujo, STC. Behaviors of nursing students in the learning of communication 
in mental health. Rev Enferm UFPE[Internet]. 2017[cited 2017 Nov 20];11(10):3878-84. Available from: https://periodicos.ufpe.br/revistas/ revistaenfermagem/article/view/69710/24400

4. Rodrigues J, Pinho LB, Spricigo JS, Santos SMA. Uso da criatividade e da tecnologia no ensino da crise em enfermagem psiquiátrica e saúde mental. SMAD Rev Eletrôn Saúde Ment Alcool Drog[Internet]. 2010[cited 2017 Nov 21];6(1):1-13. Available from: http:// pepsic.bvsalud.org/pdf/smad/v6n1/11.pdf

5. Santos I, Gauthier JHM. Sociopoética: para uma perspectiva estética do pesquisar/cuidar/educar em enfermagem. Rev Eletr Enf[Internet]. 2013[cited 2018 Mar 12];15(1):12. Available from: https://www.fen.ufg.br/fen_revista/v15/n1/pdf/v15n1a01.pdf

6. Bardin L. Análise de Conteúdo. São Paulo: Edições 70, 2011.

7. Pereira WR, Ribeiro MRR, Depes VBS, Santos NC. Emotional competencies in the process of teaching and learning in nursing, from the perspective of the neurosciences. Rev Latino-Am Enfermagem[Internet]. 2013[cited 2017 Nov 22];21(3):663-9. Available from: http://www.scielo.br/pdf/rlae/v21n3/0104-1169-rlae-21-03-0663.pdf

8. Azevedo AL, Araújo STC, Pessoa Jr JM, Silva J, Santos BTU, Bastos SSF. Communication of nursing students in listening to patients in a psychiatric hospital. Esc Anna Nery Rev Enferm[Internet]. 2017 Jun[cited 2017 Dec 17];21(3):e20160325. Available from: http://www.scielo.br/pdf/ean/v21n3/1414-8145-ean-2177-9465-EAN-2016-0325.pdf

9. Dutra VFD, Bossato HR, Oliveira RMP. Mediating autonomy: an essential care practice in mental health. Esc Anna Nery Rev Enferm[Internet]. 2017[cited 2017 Dec 14];21(3):e20160284. Available from: http://www.scielo.br/pdf/ean/v21n3/1414-8145ean-2177-9465-EAN-2016-0284.pdf

10. Happell B, Wynaden D, Tohotoa J, Byrne L. Mental health lived experience academics in tertiary education: the views of nurse academics. Nurse Educ Today[Internet]. 2015[cited 2017 Nov 25];(35):113-7. Available from: http://www.nurseeducationtoday. com/article/S02606917(14)00238-X/pdf

11. Hertenstein MJ, Keltner D. Gender and the communication of emotion via touch. Sex Roles[Internet]. 2011 [cited 2017 Nov 11];64(1-2):70-80. Available from: https://www.ncbi.nlm.nih.gov/pmc/articles/PMC3016097/pdf/11199_2010_Article_9842.pdf

12. Malpica CR. Definición, contenido y límites de la psiquiatría contemporánea. Salud Ment[Internet]. 2012 [cited 2017 Dec 12];35(3):181-8. Available from: http://www.scielo.org.mx/pdf/sm/v35n3/v35n3a1.pdf

13. Chan ZC. A qualitative study on non-verbal sensitivity in nursing students. J Clin Nurs[Internet]. 2013[cited 2017 Nov 22];22(1314):1941-50. Available from: http://www.ncbi.nlm.nih.gov/pubmed/23745644

14. Montis IA, Brüne M, Fresan A, Vida OF, Javier V, Saracco R, et al. Recognition of facial expression of the emotions and their relation to attachment styles and psychiatric symptoms: preliminary study on psychiatric residents. Salud Ment[Internet]. 2013 [cited 2017 Nov 21];36(2):95-100. Available from: http://www.scielo.org.mx/pdf/sm/v36n2/v36n2a1.pdf

15. Schimidt TCG, Silva MJP. An approach to touching while providing high-quality affective health care to hospitalized elderly patients. Rev Esc Enferm USP[Internet]. 2013[cited 2017 Nov 26];47(2):426-32. Available from: http://www.scielo.br/pdf/reeusp/ v47n2/en 22.pdf

16. Maynart WHC, Albuquerque MCS, Brêda MZ, Jorge JS. Qualified listening and embracement in psychosocial care. Acta Paul Enferm[Internet]. 2014[cited 2017 Dec 05];27(4):300-4. Available from: http://www.scielo.br/pdf/ape/v27n4/en_1982-0194ape-027-004-0300.pdf

17. Miller LC, Russel CL, Cheng AL, Skarbek AJ. Evaluating undergraduate nursing students' self-efficacy and competence in writing: Effects of a writing intensive intervention. Nurse Educ Pract[Internet] 2015[cited 2017 Dec 04];15(3):174-80. Available from: http:// www.nurseeducationinpractice.com/article/S1471-5953(14)00185-1/fulltext

18. Doolen J, Giddings M, Johnson M, Nathan GG, Badia LO. An evaluation of mental health simulation with standardized patients. Int J Nurs Educ Scholarsh[Internet]. 2014[cited 2017 Nov 31];11(1):1-8. Available from: http://www.ncbi.nlm.nih.gov/pubmed/24620017

19. Bjork IT, Berntsen K, Brynildsen G, Hestetun M. Nursing students' perceptions of their clinical learning environment in placements outside traditional hospital settings. J Clin Nurs[Internet]. 2014[cited 2017 Nov 30];(23):2958-67. Available from: https://www. ncbi.nlm.nih.gov/pmc/articles/PMC4263152/pdf/jocn0023-2958.pdf

20. Santos LM, Oliveira RMP, Dutra VFD, Porto IS. The process of knowledge transference: a matter concerning of teaching of psychiatric nursing. Esc Anna Nery Rev Enferm[Internet]. 2017[cited 2017 Dec 01];21(3):e20160356. Available from: http://www.scielo.br/ pdf/ean/v21n3/1414-8145-ean-2177-9465-EAN-2016-0356.pdf

21. El-Jaick FS, Berg KB, Peixoto MM, Serpa Jr OD. Usuários da saúde mental como educadores: o que suas narrativas podem nos ensinar? Interface[Internet]. 2016[cited 2017 Dec 11];20(56):227-38. Available from: http://www.scielo.br/pdf/icse/v20n56/18075762-icse-1807-576220150073.pdf 